\title{
Ekstrak Monascus purpureus (angkak) mampu Menurunkan GM-CSF pada Penderita Demam Berdarah
}

\author{
Indro Harianto*, Rivan Virlando Suryadinata \\ Fakultas Kedokteran, Universitas Surabaya (UBAYA), Surabaya, Indonesia
}

\section{Article Information :}

Submission: Jul 18, 2021; Revised:Dec 17, 2021; Accepted:Dec 29, 2021; Available online: Dec 31,2021

*Corresponding author : drindro@staff.ubaya.ac.id

\begin{abstract}
ABSTRAK
Penyakit demam berdarah akibat infeksi virus dengue dapat dikategorikan sebagai penyakit dengan self limiting disease dengan masa penyembuhan sekitar 7 hari. Pada perjalanan penyakit tersebut, seringkali ditemukan berbagai macam penyulit yang dapat menyebabkan terjadinya komplikasi hingga kematian. Berbagai permasalahan klinis yang ditimbulkan akan mengakibatkan penurunan kondisi penderita secara umum. Salah satu komplikasi berbahaya yang dapat ditimbulkan dari demam berdarah adalah timbulnya syok dan perdarahan. Pemberian asupan ekstrak Monascus purpureus mampu menurunkan kadar Granulocyte-Macrophage Colony Stimulating Factor (GM-CSF), sehingga mampu mencegah komplikasi lebih lanjut. Penelitian ini bertujuan untuk mengetahui pengaruh asupan ekstrak Monascus purpureus terhadap perubahan kadar GM-CSF pada penderita demam berdarah. Penelitian ini menggunakan metode eksperimental pada 2 kelompok yaitu kelompok kontrol dan kelompok perlakuan yang diberikan asupan ekstrak Monascus purpureus selama 3 hari. Jumlah sampel yang digunakan pada setiap kelompok berjumlah 15 orang. Parameter yang digunakan pada penelitian tersebut adalah kadar GM-CSF setelah pemberian perlakuan. Hasil penelitian memperlihatkan adanya perbedaan kadar GM-CSF pada kelompok kontrol dan kelompok perlakuan $(p<0,05)$. Sehingga dapat disimpulkam pemberian asupan ekstrak Monascus purpureus selama 3 hari mampu menurunkan kadar GM-CSF penderita demam berdarah.
\end{abstract}

Kata kunci : monascus purpureus, demam Berdarah, GM-CSF

\section{ABSTRACT}

Dengue fever caused by dengue virus infection can be categorized as a self-limiting disease with a healing period of about 7 days. Various complications are often found which can lead to complications and even death. Clinical problems caused will result in a decrease in the patient's condition in general. One of the dangerous complications that can result from dengue fever is shock and bleeding. The intake of Monascus purpureus extract was able to reduce levels of Granulocyte-Macrophage Colony Stimulating Factor (GM-CSF). This study aims to determine the effect of intake of Monascus purpureus extract on changes in GMCSF levels in patients with dengue fever. This study used an experimental method in 2 groups, namely the control group and the treatment group which were given the intake of Monascus purpureus extract for 3 days. The number of samples used in each group 
amounted to 15 people. The parameters used in this study were GM-CSF levels after treatment. The results showed that there were differences in GM-CSF levels in the control group and the treatment group $(p<0.05)$. So it can be concluded that the intake of Monascus purpureus extract for 3 days can reduce GM-CSF levels in dengue fever patients.

Keywords: monascus purpureus, dengue fever, GM-CSF

\section{PENDAHULUAN}

Demam berdarah adalah penyakit yang diakibatkan oleh infeksi virus dengue melalui gigitan nyamuk aedes (Guo et al., 2017). Penyakit demam berdarah telah menjadi masalah kesehatan global karena telah menjadi endemik dan mengenai hampir 100 negara, yang sebagian besar berada di daerah tropis dan subtropis. Peningkatan kejadian dan distribusi geografis virus dengue telah meningkat pesat hingga mencapai 30 kali lipat. Jumlah kasus demam berdarah diperkirakan mencapai 100 juta kasus setiap tahunnya (Tang and Ooi, 2012).

Demam berdarah ditularkan melalui gigitan dari Aedes aegypti, sehingga menyebabkan infeksi Dengue Virus (DENV). Virus ini merupakan virus RNA yang digolongkan pada genus Flavivirus dari keluarga Flaviviridae dengan memiliki 4 serotipe utama (DENV 1-4) yang secara antigen berbeda satu sama lain. Setiap serotipe DENV secara filogenetika berbeda sehingga setiap serotipe dapat dianggap sebagai virus yang terpisah (Nedjadi et al., 2015). Tiga serotipe dengue dari empat jenis serotipe yaitu DENV 1-3 ditemukan di negara arab dan Yaman. Selain itu, strain DENV-1 yang diisolasi di Arab Saudi menunjukkan kesamaan genetik yang tinggi dengan strain DENV-1 yang diisolasi dari populasi Asia. Hal ini memperlihatkan bahwa kemungkinan penyebaran DENV-1 hingga ke Asia dikarenakan oleh perpindahan penduduk (Madani et al., 2013; Azhar et al., 2015).

Infeksi DENV merupakan penyebab utama penyakit di daerah tropis dan subtropis. Infeksi dengan salah satu serotipe DENV akan menimbulkan gejala asimtomatik pada sebagian besar kasus atau dapat mengakibatkan munculnya gejala klinis ringan seperti sindrom mirip flu hingga yang paling parah yang ditandai dengan koagulopati, peningkatan kerapuhan pembuluh darah, dan permeabilitas (demam berdarah dengue).
Selain itu, pada tahap yang terakhir dapat berkembang menjadi syok hipovolemik atau dikenal sebagai sindrom syok dengue (Montoya et al., 2013).

Penyakit demam berdarah di Asia terjadi dengan komplikasi lebih berisiko pada anak-anak yang terinfeksi DENV dengan usia kurang dari 15 tahun dibandingkan pada orang dewasa. Berbagai macam gejala penyerta demam berdarah ditandai dengan timbulnya demam yang cepat disertai dengan kombinasi nyeri kepala parah, nyeri daerah retro-orbital, mialgia, artralgia, dan rasa tidak nyaman pada gastrointestinal, serta timbulnya ruam. Selain itu, perdarahan minor dapat terjadi berupa petekie, epistaksis, dan perdarahan gingiva (Anderson et al., 2014). Leukopenia merupakan gejala umum yang kadang disertai dengan trombositopenia sebagai tanda-tanda hemoragik. Demam berdarah diklasifikasikan dalam empat kelas (I sampai IV). Demam Berdarah Dengue derajat I dan II merupakan kasus ringan tanpa syok, namun bila mencapai derajat III dan IV akan disertai syok (Halstead, 2015).

Risiko perkembangan demam berdarah dapat diprediksi melalui peningkatan suhu dan tingkat trombositopenia. Penderita dengan jumlah trombosit kurang dari $30.000 / \mathrm{mm}^{3}$ memiliki dua kali lipat kemungkinan hasil yang buruk. Pada kondisi demam akut biasanya terjadi sekitar 2-7 hari dan muka agak kemerahan, kulit terkena eritema, tubuh terasa nyeri, mialgia, artralgia, dan nyeri pada kepala. Anoreksia, mual, dan muntah. Gambaran klinis ini ditandai sebagai kasus demam berdarah yang tidak parah. Tandatanda klinis lain perlu diperhatikan agar dapat segera mengenali perkembangan ke fase kritis, dan dapat membantu membedakan kasus demam berdarah yang tidak parah dan yang parah. Gejala awal yang dapat digunakan adalah sakit perut, mual muntah, perdarahan mukosa, lesu, gelisah, dan hepatomegali lebih dari $2 \mathrm{~cm}$ 
terkait dengan parameter laboratorium seperti peningkatan hematokrit (HCT) akan mengakibatkan penurunan jumlah trombosit yang cepat. Pada perdarahan ringan seperti petechiae dan pada daerah membran mukosa (misalnya, gusi dan hidung) (Barniol et al., 2011). Perawatan darurat dan rujukan harus segera dilakukan pada fase kritis penyakit, yaitu ketika demam berdarah yang parah yang ditandai dengan kebocoran plasma sehingga menyebabkan terjadinya syok dengue yang disertai dengan sesak, perdarahan hebat yang ditunjukkan oleh perdarahan pervaginam yang masif. wanita usia subur), dan perdarahan gastrointestinal dan/atau kerusakan organ yang parah (kerusakan hati, gangguan ginjal, kardiomiopati, ensefalopati, atau ensefalitis) (Azeredo et al., 2015). Faktor yang mempengaruhi tingkat keparahan dari demam berdarah adalah penurunan kadar trombosit. Granulocyte-Macrophage Colony Stimulating Factor (GM-CSF) merupakan polipeptida pada permukaan reseptor sel dan berfungsi sebagai sitokin untuk mengatur pertumbuhan, ekspresi gen, dan diferensiasi beberapa sel hematopoitik meliputi granulosit, makrofag, eosinofil, dan eritrosit. Selain itu, GM-CSF bersama dengan IL-3 merangsang pembentukan megakariosit yang merupakan awal pembentukan dari trombosit (Lukens et al., 2012).

Monascus purpureus dapat meningkatkan jumlah trombosit dikarenakan adanya kandungan lovastatin yang akan mengoksidasi LDL dan merangsang monosit dan megakariosit untuk bermigrasi ke endothelium untuk berubah menjadi makrofag dan trombosit aktif (Prayoga and Tjiptaningrum, 2016). Pada penelitian sebelumnya telah dilakukan dengan menggunakan hewan coba yang terinfeksi virus DEN 3, memperlihatkan adanya peningkatan trombosit melalui pemberian Monascus purpureus (Triyono, 2020). Perubahan kadar trombosit juga dipengaruhi oleh Granulocyte-Macrophage ColonyStimulating Factor (GM-CSF) berperan untuk pematangan dan aktivasi fungsional sel hematopoietik. Peran penting lainnya adalah menekan reaksi antibodi yang berlebihan terhadap infeksi virus dengue, sehingga tidak terjadi respon inflamasi yang tidak terkontrol (Bhattacharya et al., 2015). Hal ini dikarenakan respon inflamasi yang berlebihan akan mengakibatkan kerusakan dan kematian sel (Suryadinata et al., 2021). Penelitian ini merupakan penelitian pertama yang meneliti efek pemberian ekstrak Monascus purpureus terhadap kadar GMCSF. Penelitian ini bertujuan untuk mengukur dan membandingkan perbaikan laboratorium kadar trombosit dan GM-CSF pada penderita demam berdarah melalui pemberian Monascus purpureus.

\section{METODE PENELITIAN}

Penelitian ini adalah penelitian eksperimental pada penderita demam berdarah melalui pemberian ekstrak Monascus purpureus. Penelitian ini menggunakan penderita infeksi virus dengue yang terbukti secara klinis dan laboratoris dengan membagi menjadi 2 kelompok yaitu kelompok kontrol dan kelompok perlakuan. Jumlah sampel yang digunakan pada penelitian ini adalah 15 orang pada tiap kelompok. Kelompok kontrol diberikan terapi standar penanganan demam berdarah, sedangkan kelompok perlakuan diberikan tambahan ekstrak Monascus purpureus sebanyak 50 mg selama 3 hari

Sampel penelitian harus memenuhi kriteria inklusi adalah penderita berusia diatas 13 tahun atau kurang dari 65 tahun dengan infeksi virus Dengue, demam saat masuk RS kurang dari 5 hari, hasil positif pada pemeriksaan IgM dan/atau IgG anti Dengue yang dilakukan setelah hari kelima demam dan bersedia mengikuti penelitian yang dibuktikan dengan menandatangani inform consent. Pada penelitian in terdapat kriteria eksklusi yaitu pasien telah menerima tranfusi whole blood, packed red cell, platelet, fresh frozen plasma selama perawatan serta mengalami komplikasi berat seperti Disseminated Intravascular Coagulation, syok, perdarahan sedang / berat (DBD derajat III / IV), penurunan kesadaran (ensefalopati) dan penderita dengan penyakit penyerta yang berat seperti kelainan hematologis (ITP, leukemia, thalasemia, hemofilia dan lainlain), penyakit jantung (Penyakit jantung bawaan, miokarditis, gagal jantung) dan penyakit paru (asma bronchiale dan lain- 
lain). Penilaian kadar GranulocyteMacrophage Colony-Stimulating Factor (GM-CSF) dilakukan setelah 3 hari pemberian ekstrak Monascus purpureus melalui pengambilan darah vena. Data yang sudah diperoleh akan dilakukan uji Ttest untuk melihat adanya perbedaan antara kelompok kontrol dengan kelompok perlakuan.

\section{HASIL PENELITIAN}

Distribusi frekuensi pada penelitian tabel 1 memperlihatkan usia jenis kelamin, lama demam dan rerata suhu. Berdasarkan tabel 1. menunjukkan bahwa rerata umur subyek penelitian pada kelompok kontrol sebesar 23,53 $\pm 10,49$ dan kelompok perlakuan sebesar $30,53 \pm 11,63$. Sedangkan jenis kelamin memberikan gambaran bahwa penderita demam berdarah didominasi oleh laki-laki, pada kelompok kontrol jumlah laki-laki sebanyak 12 orang dan kelompok perlakuan sebesar 11 orang. Rerata jumlah hari panas kelompok kontrol pada penderita saat masuk rumah sakit adalah 4,87 $\pm 0,35$ dan kelompok perlakuan pada hari 4,6 $\pm 0,63$. Rerata suhu aksila kelompok kontrol tidak berbeda jauh dari kelompok perlakuan yaitu $37,74 \pm 0,18$ dan $37,73 \pm 0,19$. Berdasarkan tabel 2. menunjukkan bahwa kelompok kontrol memiliki rerata sebesar $1,140 \pm 1,01$, sedangkan pada kelompok perlakuan sebesar $0,773 \pm 0,6$. Pada uji perbedaan antar kelompok didapatkan $p$ lebih kecil dari 0,05 sehingga dapat disimpulkan adanya perbedaan kadar GMCSF pada kedua kelompok.

Tabel 1. Karakteristik umum penderita infeksi dengue

\begin{tabular}{lcc}
\multicolumn{1}{c}{ Variabel } & $\begin{array}{c}\text { Kelompok Kontrol } \\
(\mathbf{n = 1 5 )}\end{array}$ & $\begin{array}{c}\text { Kelompok Perlakuan } \\
(\mathbf{n}=\mathbf{1 5})\end{array}$ \\
\hline Usia (tahun) & $23,53 \pm 10,49$ & $30,53 \pm 11,63$ \\
\hline Jenis Kelamin: & & \\
\hline Laki-laki & 12 & 11 \\
\hline Perempuan & 3 & 4 \\
\hline Total hari demam & $4,87 \pm 0,35$ & $4,6 \pm 0,63$ \\
\hline Suhu aksila $\left({ }^{\circ} \mathrm{C}\right)$ & $37,74 \pm 0,18$ & $37,72 \pm 0,19$ \\
\hline
\end{tabular}

Tabel 2. Uji Kadar GM-CSF (pg/ml) pada setiap kelompok

\begin{tabular}{lccc}
\hline \multicolumn{1}{c}{ Kelompok } & $\begin{array}{c}\text { Jumlah } \\
\text { Penderita }\end{array}$ & $\begin{array}{c}\text { Rerata } \\
\text { GM-CSF }\end{array}$ & P value \\
\hline Kontrol & 15 & $1,140 \pm 1,01$ & 0,000 \\
Perlakuan & 15 & $0,773 \pm 0,6$ & 0,6 \\
\hline
\end{tabular}

\section{PEMBAHASAN}

Pada penelitian ini baik dari kelompok perlakuan maupun kelompok uji didapatkan perubahan kadar Granulocyte-Macrophage Colony-Stimulating Factor (GM-CSF). Dari 15 penderita demam berdarah yang menjadi kelompok perlakuan mengalami perubahan jumlah kadar GM-CSF lebih rendah dibandingkan dengan kelompok kontrol. Peningkatan kadar GM-CSF pada penderita demam berdarah memberikan gambaran bahwa akan berisiko mengalami manifestasi klinis yang berat (Bhattacharya et al., 2015). Hal ini dikarenakan Interferon Gamma (IFN-y) dan GM-CSF mengaktivasi Mononuclear monocytes yang pada akhirnya memproduksi beberapa faktor seperti Interleukin-1 $\beta$ dan Monocyte chemoattractant protein-1 (MCP-1) mempengaruhi permeabilitas vaskuler menyebabkan plasma leakage dan haemoconcentration (Lee et al., 2013; Xu et al, 2015).

Penurunan kadar GM-CSF akan sejalan dengan peningkatan jumlah trombosit. Hal ini dikarenakan pada infeksi demam berdarah akan dapat mempengaruhi peningkatan jumlah trombosit melalui efek antiinflamasinya atau berdampak pada proses megakariopoiesis dan trombopoiesis pada sumsum tulang 
yang selanjutnya mempengaruhi kadar GMCSF (Puc et al., 2021).

Pemberian Monascus purpureus dengan kandungan monacolin $K$ yang memiliki kesamaan struktur dengan lovastatin memiliki efek menyerupai statin. Selain itu, kandungan berbagai zat lain seperti dimerumic acid (antioxidant), serta metabolit ankavlafin dan monascin juga dapat memberikan efek antiinflamasi (Lin et al, 2011). Pemberian ekstrak Monascus purpureus pada penelitian terdahulu juga mampu meningkatkan jumlah trombosit yang diduga melalui efek pada peningkatan megakariopoiesis dan trombopoiesis di sumsum tulang atau efek antiinflamasi metabolitnya (Muharni et al., 2011). Namun sejauh ini belum ada data tentang efek statin pada produksi GM-CSF.

Penelitian ini merupakan penelitian pertama yang meneliti efek pemberian ekstrak Monascus purpureus terhadap kadar GM-CSF, sehingga diharapkan dapat memberikan pandangan terkait pengaruh ekstrak Monascus purpureus pada terapi infeksi dengue untuk penelitian lebih lanjut.

\section{KESIMPULAN}

Pemberian ekstrak Monascus purpureus pada penderita demam berdarah selama 3 hari mampu menurunkan kadar GM-CSF dalam darah

\section{REFERENSI}

Anderson, K.B., Gibbons, R.V., Cummings, D.A., Nisalak, A., Green, S., Libraty, D.H., Jarman, R.G., Srikiatkhachorn, A., Mammen, M.P., Darunee, B., Yoon, I.K., Endy, T.P. (2014). A shorter time interval between first and second dengue infections is associated with protection from clinical illness in a school-based cohort in Thailand. $J$ Infect Dis. 209(3):360-8.

Azeredo, E., Monteiro, R., Pinto, L. (2015). Thrombocytopenia in Dengue: Interrelationship between Virus and the Imbalance between Coagulation and Fibrinolysis and Inflammatory Mediators. Mediators Inflamm. 313842.

Azhar, E.I., Hashem, A.M., El-Kafrawy, S.A., Abol-Ela, S., Abd-Alla, A.M., Sohrab, S.S., et al. (2015). Complete genome sequencing and phylogenetic analysis of dengue type 1 virus isolated from Jeddah, Saudi Arabia. Virol J. $12: 1$

Barniol, J., Gaczkowski, R., Barbato, E.V., da Cunha, R.V., Salgado, D., Martínez, E., Segarra, C.S., Sandoval, E.B., Mishra, A., et al. (2011). Usefulness and applicability of the revised dengue case classification by disease: multicentre study in 18 countries. BMC Infect Dis.11:106.

Bhattacharya, M., Elshabrawy, H.A., Alharshawi, K., Kumar, P., and Prabhakar, B.S. (2015). GM-CSF: An Immune Modulatory Cytokine that can Suppress Autoimmunity. Cytokine. 75(2): 261271.

Guo, C., Zhou, Z., Wen, Z., Liu, Y., Zeng, C., Xiao, D. (2017). Global Epidemiology of Dengue Outbreaks in 1990-2015: A Systematic Review and Meta-Analysis. Front Cell Infect Microbiol. 7: 317.

Halstead, S.B. (2015). Pathogenesis of Dengue: Dawn of a New Era. F1000 Research. 4:1353

Lee, I.,Hsieh, C., Chen, R., Yang, Z., Wang, L., Chen, C., Liu, C., Huang, C., Lin, C., Chen, Y., Yang, K., Liu, J. (2013). Increased Production of Interleukin-4, Interleukin-10, and GranulocyteMacrophage Colony-Stimulating Factor by Type 2 Diabetes' Mononuclear Cells Infected with Dengue Virus, but Not Increased Intracellular Viral Multiplication. Biomed Res Int. 965853.

Lin, C.P., Lin, Y.L., Huang, P.O., Tsai, H.S., Chen, Y.H. (2011). Inhibition of endotelial adhesion molecule expression by Monascus purpureusfermented rice metabolites monakolin $\mathrm{K}$, ankaflavin and monascin. $J$ Sci Food Agri. 91:1751-58.

Lukens, J.R., Barr, M.J., Chaplin, D.D., Chi, H., Kanneganti, T.D. (2012). Inflammasome-derived IL-1 $\beta$ regulates the production of GM-CSF by CD4(+) T cells and $\mathrm{\gamma} \delta \mathrm{T}$ cells. $J$ Immunol. 188(7):3107-15.

Madani, T.A., Abuelzein, E., Al-Bar, H.M., Azhar, E.I., Kao, M., Alshoeb, H.O., et al. (2013). Outbreak of viral hemorrhagic fever caused by dengue virus type 3 in Al-Mukalla, Yemen. BMC Infect Dis. 14(13):136. 
Montoya, M., Gresh, L., Mercado, J.C., Williams, K.L., Vargas, M.J., Gutierrez, G., Kuan, G., Gordon, A., Balmaseda, A., Harris, E. (2013). Symptomatic versus inapparent outcome in repeat dengue virus infections is influenced by the time interval between infections and study year. PLoS Negl Trop Dis. 7(8):e2357.

Muharni, S., Almahdy, A., Martini, R.D. (2011). Effect of the use of supplements Psidii folium extract (Psidium guajava linn.) and red fermented rice (Monascus purpureus) in increase of thrombocytes at Dengue Hemorrhagic Fever (DHF) science in the installation of disease in hospital $d r$. M. Djamil Padang.

Nedjadi, T., El-Kafrawy, S., Sohrab, S., Despres, $\quad$ P., Damanhouri, G., Azhar, E. (2015). Tackling dengue fever: Current status and challenges. Virol J. 12: 212

Prayoga, M.J. and Tjiptaningrum, A. (2016). Pengaruh Pemberian angkak (beras fermentasi monascus purpureus) dalam meningkatkan kadar trombosit pada penderita demam berdarah 531518. dengue. Medical Journal of Lampung University. 5(5):6-13

Puc, I., Ho, T., Yen, K., Vats, A., Tsai, J., Chen, P., Chien, Y., Yo, Y., Perng, G. (2021). Cytokine Signature of Dengue Patients at Different Severity of the Disease. Int $J$ Mol Sci.22(6): 2879 .

Suryadinata, R.V., Lorensia, A., Sefania, K. (2021). Effectiveness of Lime Peel Extract (Citrus aurantifolia Swingle) against C-Reactive Protein Levels in Alloxan-Induced Wistar Rats. Global Medical and Health Communication. 9 (1), 23-28

Tang, K.F. and Ooi, E.E. (2012). Diagnosis of dengue: An update. Expert Rev Anti Infect Ther. 10(8):895-907.

Triyono, EA. (2020). The mechanism of the effects of Monascus jmbA rice on increased platelet count in Wistar rats infected with Dengue virus serotype 3. Infect Dis Rep. 12(1): 8720.

Xu, N., Li, X., Zhong, Y. (2015). Inflammatory Cytokines: Potential Biomarkers of Immunologic Dysfunction in Autism Spectrum Disorders. Mediators Inflamm. 